\title{
PENENTUAN TINGKAT KESEGARAN DAGING AYAM MENGGUNAKAN LABEL PINTAR BERBASIS EKSTRAK ANTOSIANIN UBI JALAR UNGU
}

\section{DETERMINATION OF FRESHNESS LEVEL FOR CHICKEN MEAT USING SMART LABEL BASED ON EXTRACT OF PURPLE SWEET POTATO ANTHOCYANIN}

\author{
Andrew Setiawan Rusdianto*, Andi Eko Wiyono, dan Nina Tauvika \\ Jurusan Teknologi Industri Pertanian, Fakultas Teknologi Pertanian Universitas Jember \\ Jl. Kalimantan 3 No.37 Kampus Tegalboto, Jember \\ *Email korespondensi: andrew.ftp@unej.ac.id
}

Diterima 18-11-2020, diperbaiki 10-05-2021, disetujui 21-05-2021

\begin{abstract}
Chicken meat is perishable food so it has a short shelf life. Nowadays, it has emerged Smart packaging equipped with smart label. Smart label based on extract anthocyanin purple sweet potato is solution to be used a determination the level of chicken meat freshness. The purpose of this study was to develop a smart label prototype based on anthocyanin extract and to determine its feasibility to determine the level of chicken meat freshness. Extract purple sweet potato anthocyanin was obtained by maceration method using methanol $96 \%$ solvent acidified with $\mathrm{HCl} 1 \%$. The results of the anthocyanin extract had a pH of $5.58 \pm 0.013$ and value of anthocyanin $62.79 \pm 0.558 \mathrm{mg} / 100 \mathrm{~g}$. The smart label shows the level of the chicken meat freshness with a change in color, where the purple color indicates the fresh chicken meat, the faded purple color indicates that the chicken is stay fresh, and the bluish purple smart label indicates the chicken is not fresh. The results of the feasibility of smart labels on $\mathrm{pH}$ stability experienced a color change in both acidic and alkaline situations, but were more stable in acidic conditions.
\end{abstract}

Keywords: chicken meat, smart label, extract anthocyanin

\begin{abstract}
ABSTRAK
Daging ayam merupakan bahan pangan yang bersifat mudah rusak dan memiliki umur simpan yang pendek. Dewasa ini, telah muncul kemasan pintar (Smart packaging) yang dilengkapi label pintar. Label pintar berbasis ekstrak antosianin ubi jalar ungu dirasa dapat menjadi solusi yang tepat untuk digunakan sebagai penentu tingkat kesegaran daging ayam. Tujuan penelitian ini adalah mengembangkan prototype label pintar ekstrak antosianin ubi jalar ungu dan mengetahui kelayakannya dalam penentuan tingkat kesegaran daging ayam. Esktrak ubi jalar ungu diperoleh dengan metode maserasi menggunakan pelarut metanol $96 \%$ yang diasamkan $\mathrm{HCl} \mathrm{1 \%}$. Hasil ekstrak antosianin memiliki pH sebesar $5.58 \pm$ 0.013 dan nilai kadar antosianin sebesar $62.79 \pm 0.558 \mathrm{mg} / 100 \mathrm{~g}$. Label pintar menunjukkan tingkat kesegaran daging ayam dengan adanya perubahan warna, dimana warna ungu muda menandakan daging ayam segar, warna ungu pudar menandakan bahwa daging ayam masih segar, dan label pintar warna ungu kebiru-biruan menandakan daging ayam pada kondisi tidak segar. Hasil kelayakan label pintar pada stabilitas $\mathrm{pH}$ mengalami perubahan warna baik pada suasana asam dan suasana basa, tetapi lebih stabil pada suasana asam.
\end{abstract}

Kata kunci: daging ayam, label pintar, ekstrak antosianin 


\section{PENDAHULUAN}

Daging ayam merupakan bahan pangan bersifat perishable food. Kualitas daging ayam sebagian besar disebabkan oleh penanganan yang kurang baik pada saat pemotongan hingga pemasaran. Daging ayam yang dijual secara terbuka menjadi penyebab penurunan mutu daging ayam, karena tempat penjualan yang kurang higenis dan konsumen memilih daging ayam dengan melakukan kontak langsung dapat mengakibatkan daging ayam terkontaminasi oleh mikroorganisme. Kontaminasi mikroorganisme akan mempercepat penurunan mutu sehingga umur simpan daging ayam semakin pendek. Aktivitas bakteri yang menghasilkan volatile amin menyebabkan perubahan $\mathrm{pH}$ pada daging ayam (Ananta et al., 2017). Salah satu upaya untuk memperlambat penurunan mutu daging ayam adalah dengan pengemasan.

Kemasan mengalami perkembangan yang semakin meningkat, hal ini dibuktikan dengan munculnya kemasan pintar (smart packaging). Smart packaging digunakan untuk memonitor kondisi pangan yang dikemas. Smart packaging dilengkapi dengan label pintar yang diletakkan internal kemasan untuk memberikan informasi kualitas produk yang dikemas (Riyanto et al., 2014). Label pintar dapat digunakan konsumen untuk menentukan tingkat kesegaran daging ayam tanpa bersentuhan langsung dan membuka kemasan sehingga mengurangi kontaminasi mikroorganisme pada daging. Label pintar memberikan informasi perubahan mutu bahan yang dikemas dengan menunjukkan perubahan visual yaitu warna label. Label pintar dilengkapi dengan indikator, salah satunya indikator $\mathrm{pH}$.

Pendeteksi perubahan $\mathrm{pH}$ dapat menggunakan pewarna kimia, namun penggunaan pewarna kimia memiliki kemungkinan adanya efek toksinitas apabila tidak sengaja tertelab atau mengalami kontak dengan produk, sehingga tidak menjamin keamanan produk. Alternatif untuk mengatasi permasalahn tersebut adalah menggunakan pewarna alami yang sensitif terhadap perubahan $\mathrm{pH}$ yaitu antosianin. Antosianin merupakan senyawa organik bewarna merah hingga ungu yang dapat mengalami perubahan warna dalam suasana asam dan basa. $\mathrm{pH}$ tinggi antosianin bewarna biru atau tidak bewarna dan $\mathrm{pH}$ rendah bewarna merah (Ananta et al., 2017).

Tanaman yang berpotensi memiliki kandungan antosianin tinggi adalah ubi jalar ungu. Ekstrak antosianin ubi jalar ungu dapat digunakan untuk mendeteksi tingkat kesegaran susu (Imawan et al., 2018). Antosianin ubi jalar ungu dapat dimanfaatkan sebagai pewarna alami pada label pintar untuk mendeteksi tingkat kesegaran daging ayam.

Tujuan dari penelitian ini adalah mengembangkan prototype label pintar berbasis ekstrak antosianin ubi jalar ungu. Selain itu untuk mengetahui kelayakan label pintar sebagai indikator tingkat kesegaran daging ayam pada penyimpanan suhu ruang dan suhu dingin.

\section{BAHAN DAN METODE}

\section{Bahan dan Peralatan}

Bahan yang digunakan adalah daging ayam bagian dada usia 4-6 minggu diperoleh dari "RPH Jalan Sumatra" Jember, ubi jalar ungu varietas "Antin" usia panen 4 bulan dari Kaliwates Jember, metanol 96\%, HCL 1\%, larutan dapur kalium klorida $\mathrm{pH} 1$, larutan natrium asetat $\mathrm{pH} 4.5, \mathrm{NaOH}$, kertas whatman no 1 cat 1001, styrofoam dan plastic warp. Alat yang digunakan diantaranya adalah hand $\mathrm{pH}$ meter, colour reader, spektrofotometer UV - Vis, oven, printer canon MP 258 dan sofware ImageJ.

\section{Metode Pembuatan Ekstrak Antosianin Ubi Jalar Ungu}

Ekstraksi antosianin ubi jalar ungu diperoleh mengunakan metode maserasi. 
Ubi jalar ungu dilakukan pengupasan dan pencucian. Ubi jalar ungu ditimbang $100 \mathrm{~g}$, dihaluskan dengan blender yang dicampurkan dengan pelarut $200 \mathrm{ml}$ metanol $96 \%$ dan $2 \mathrm{ml} \mathrm{HCl} \mathrm{1 \% .} \mathrm{Ubi} \mathrm{jalar}$ ungu dilakukan maserasi pada suhu ruang selama 12 jam keadaan tertutup. Ekstrak ubi jalar ungu disaring menggunakan kertas whatman no 41.

\section{Pembuatan Label Pintar}

Label pintar diperoleh dari kertas Whatman No. 1 yang diimobilisasi dengan ekstrak antosianin. Kertas Whatman No. 1 dipotong ukuran $2 \mathrm{~cm} \mathrm{X} 1 \mathrm{~cm}$, dilakukan perendaman 30 menit dan dikeringkan dalam suhu ruang (Imawan et al., 2018).

\section{Aplikasi Label Pintar}

Label pintar ekstrak antosianin ubi jalar ungu diaplikasikan dalam kemasan pintar untuk menentukan tingkat kesegaran daging ayam yang disimpan suhu ruang $\left(27^{\circ} \mathrm{C} \pm 3^{\circ} \mathrm{C}\right)$ dan suhu dingin $\left(5^{\circ} \mathrm{C} \pm 3^{\circ} \mathrm{C}\right)$. Daging ayam $100 \mathrm{~g} /$ kemasan dilakukan pengujian setiap 2 jam sekali dari jam ke-0 sampai jam ke-8, dan 4 jam sekali dari jam ke-8 sampai jam ke-24 yang disimpan pada suhu ruang $\left(27^{\circ} \mathrm{C} \pm 3^{\circ} \mathrm{C}\right)$ dan setiap hari selama 10 hari yang disimpan pada suhu dingin $\left(5^{\circ} \mathrm{C} \pm 3^{\circ} \mathrm{C}\right)$.

\section{Prosedur Analisa \\ Pengujian Ekstak Ubi Jalar Ungu}

\section{Uji $\mathrm{pH}$}

Hasil ekstrak antosianin ubi jalar ungu diambil $10 \mathrm{ml}$ dan dimasukkan ke beaker glass $50 \mathrm{ml}$, kemudian masukkan hand $\mathrm{pH}$ meter dan dilakukan pengamatan hasil $\mathrm{pH}$ dari ekstrak antosianin ubi jalar ungu (Suradi, 2012).

2. Pengukuran Kadar Antosianin

Pengukuran konsentrasi antosianin total dari pewarna alami dalam bentuk cair dilakukan dengan menggunakan metode $\mathrm{pH}$ differential yang dikembangkan oleh AOAC (2005). Pengukuran absorbansi menggunakan spektrofotometer UV-Vis pada panjang gelombang $520 \mathrm{~nm}$ dan 700nm. Nilai absorbansi dihitung dengan persamaan:

$$
\begin{aligned}
& \mathrm{A}=\left[\left(\mathrm{A}_{520}-\mathrm{A}_{700}\right) \mathrm{pH} 1-\left(\mathrm{A}_{520}-\mathrm{A}_{700}\right) \mathrm{pH} 4.5\right] \\
& \text { Antosianin }=\frac{(\mathrm{A} \mathrm{X} \mathrm{BM} \mathrm{X} \mathrm{FP} \mathrm{X} \mathrm{1000)}}{\varepsilon \times \mathrm{l}}
\end{aligned}
$$

Keterangan:

A = absorbansi

$\mathrm{A}_{510}=$ absorbansi pada panjang gelombang $510 \mathrm{~nm}$

$\mathrm{A}_{700}=$ absorbansi pada panjang gelombang 700 $\mathrm{nm}$

$\mathrm{BM}=$ berat molekul $(449,2)$

FP $=$ faktor pengenceran

$\varepsilon \quad=$ ekstingsi molar $(26900 \mathrm{~L} / \mathrm{cm})$

$\mathrm{l} \quad=$ tebal kuvet $(\mathrm{cm})$

\section{Pengujian Karakteristik Label pintar}

1. Uji Warna

Pengukuran warna label pintar menggunakan software image J. Proses pengambilan gambar dilakukan dengan melakukan proses scanning menggunakan scanner printer, hasil scan tersebut diaplikasikan pada image $J$ dan ditentukan nilai mean RGB (Reinking, 2007).

2. Uji Stabiliats $\mathrm{pH}$ Label Pintar

Label pintar ekstrak antosianin ubi jalar ungu dilakukan pengujian pada berbagai larutan buffer $\mathrm{pH}$. Label pintar pada jam ke-0 dengan $\mathrm{pH} 7$; jam ke-8 dengan $\mathrm{pH} 4$; jam ke-16 dengan $\mathrm{pH} 1$; jam ke-24 dengan $\mathrm{pH} 7$ dalam kondisi asam dan dilanjutkan pada jam ke-32 dengan pH 11. Untuk kondisi basa label pintar pada jam ke-0 dengan $\mathrm{pH} 7$; jam ke-8 dengan $\mathrm{pH}$ 9; jam ke-16 dengan $\mathrm{pH} 11$; jam ke-24 dengan pH 7 dan dilanjutkan pada jam ke-32 dengan $\mathrm{pH} 4$ dalam kondisi asam dengan menggunakan satu label pintar.

3. Uji Ketahanan Kertas Label Pintar

Uji ketahanan kertas label pintar ekstrak antosianin dilakukan dengan merendam label pintar dalam aquades selama 0 jam;12 jam; 24 jam, 36 jam dan 48 jam. Pengeringan dengan menggunakan oven selama 30 menit dengan suhu oven $105^{\circ} \mathrm{C}$ dan dilakukan perhitungan susut bobot. 


\section{Pengujian Daging Ayam}

\section{Uji pH}

Uji $\mathrm{pH}$ diukur menggunakan hand $\mathrm{pH}$ meter. Sampel daging yang dihancurkan diambil sebanyak $2 \mathrm{~g}$ dihomogenkan dengan $10 \mathrm{ml}$ aquades, kemudian masukkan hand $\mathrm{pH}$ meter sampai pengukuran digital tidak berubah lagi (Suradi, 2006).

2. Pengukuran warna $\left(L, a^{*}\right.$, dan $b^{*}$

Pengujian warna daging dilakukan dengan menggunakan alat colour rider. Menentukan target $\mathrm{L}$, a* dan $\mathrm{b}^{*}$ pada permukaan daging. Warna diukur pada tiga sisi yang berbeda (Rini dan Mahfudz, 2019).

\section{HASIL DAN PEMBAHASAN}

Pengembangan prototype Label Pintar Ekstrak Antosianin Ubi Jalar Ungu 1.pH dan Kadar Antosianin Ubi Jalar Ungu

Tabel 1. Hasil perhitungan $\mathrm{pH}$ dan kadar antosianin

\begin{tabular}{ccc}
\hline Parameter & Nilai & SD \\
\hline $\mathrm{pH}$ & 5.58 & 0.013 \\
$\begin{array}{c}\text { Kadar } \\
\text { antosianin } \\
(\mathrm{mg} / 100 \mathrm{~g})\end{array}$ & 62.579 & 0.558 \\
\hline
\end{tabular}

Hasil pH antosianin $5.58 \pm 0.013$. Ekstraksi maserasi menggunakan pelarut metanol $96 \%$ yang diasamkan dengan $\mathrm{HCl}$ $1 \%$ berlangsung dalam suasan asam, sehingga dihasilkan $\mathrm{pH}$ antosianin berada pada suasana asam. Antosianin ubi jalar ungu sensitif terhadap perubahan $\mathrm{pH}$ dari suasana asam atau suasana basa yang ditunjukan dari perubahan warna antosianin.

Kadar antosianin ubi jalar ungu 62.79 $\pm 0.558 \mathrm{mg} / 100 \mathrm{~g}$ yang dapat dilihat pada Tabel 1. Afandy et al (2017), jenis pelarut yang digunakan mempengaruhi hasil ekstraksi ubi jalar ungu. Ekstrak antosianin berada pada suasana asam, maka pigmen antosianin dalam bentuk kation flavilium dan jumlah absorbansinya akan semakin besar.

\section{Aplikasi Label Pintar}

Nilai RGB (Red, Green, Blue) pada label pintar dihitung menggunakan bantuan perangkat lunak imageJ.

Tabel 2. Nilai Mean $R G B$ Label Pintar

\begin{tabular}{|c|c|c|c|c|}
\hline \multirow[b]{2}{*}{$\begin{array}{c}\text { Ulang } \\
\text { an }\end{array}$} & \multicolumn{3}{|c|}{ Mean RGB } & \multirow[b]{2}{*}{ Gambar } \\
\hline & $\begin{array}{l}\text { Mean } \\
\text { red }\end{array}$ & $\begin{array}{l}\text { Mean } \\
\text { green }\end{array}$ & $\begin{array}{l}\text { mean } \\
\text { blue }\end{array}$ & \\
\hline 1 & 232.083 & 196.716 & 220.936 & \\
\hline 2 & 231.794 & 196.504 & 220.436 & \\
\hline $\begin{array}{l}\text { Rata- } \\
\text { rata }\end{array}$ & 231.939 & 196.610 & 220.686 & \\
\hline SD & 0.385 & 0.727 & 0.869 & \\
\hline
\end{tabular}

Nilai mean RGB pada label pintar yang memiliki nilai tertinggi adalah mean red sebesar $231.939 \pm 0.385$, sehingga nilai meanred yang digunakan pada pengujian intensitas perubahan warna label pintar. Semakin tinggi nilai mean pada salah satu warna dasar menandakan bahwa warna tersebut paling dominan dibaca oleh softwareimageJ. Fatwa et al (2020) setiap perubahan mean RGB menunjukkan perubahan rata-rata intensitas warna pada sampel.

Label pintar digunakan sebagai indikator tingkat kesegaran daging ayam dengan berbasis perubahan $\mathrm{pH}$ yang ditunjukan dengan perubahan warna label pintar. Daging ayam dikemas menggunakan styrofoam dan plastik warp, dimana label pintar diletakkan didalamnya. Desain label pintar dapat dilihat pada Gambar 1.

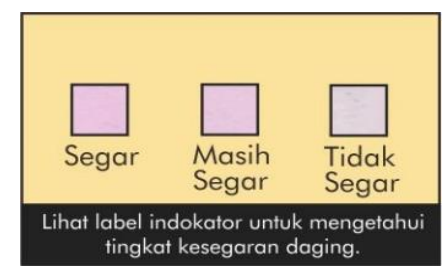

Gambar 1. Desain label pintar 
Pengaplikasian label pintar pada smart packaging untuk menentukan tingkat kesegaran daging ayam dapat dilihat pada Gambar 2.

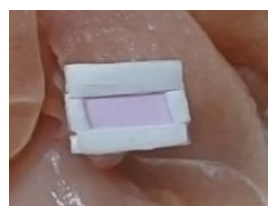

a)

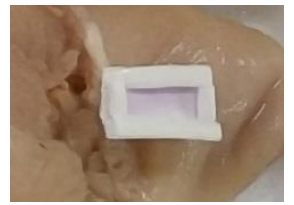

b)

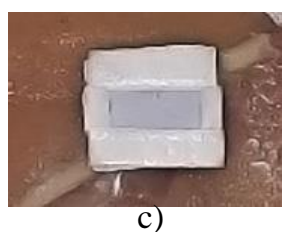

Gambar 2. Aplikasi label pintar

Gambar 2 menunjukkan bahwa label pintar mengalami perubahan warna seiring dengan lama penyimpanan daging ayam. Gambar a menunjukkan label pintar memiliki warna ungu muda yang menandakan daging ayam berada dalam kondisi segar. Gambar b menunjukkan label pintar memiliki warna ungu pudar yang menandakan bahwa daging ayam dalam kondisi masih segar. Gambar c menunjukkan label pintar memiliki warna ungu kebiru-biruan yang menandakan daging ayam berada pada kondisi tidak segar atau tidak layak untuk dikonsumsi.

Perubahan intensitas warna label terjadi karena adanya perubahan $\mathrm{pH}$ daging ayam selama proses penyimpanan baik pada kondisi suhu ruang atau suhu dingin. Farida (2015) menyebutkan bahwa pada kisaran $\mathrm{pH}$ 1-3 antosianin berada dalam bentuk kation flavilium yang bewarna merah dengan bentuk yang paling stabil, ketika $\mathrm{pH}$ naik maka akan menyebabkan hilangnya proton lebih cepat dan menyebabkan hidrasi flavilium.

\section{Tingkat Kesegaran Daging Ayam dalam Keadaan Penyimpanan Suhu Ruang dan Suhu Dingin}

\section{Kesegaran Daging Ayam pada Penyimpanan Suhu Ruang}

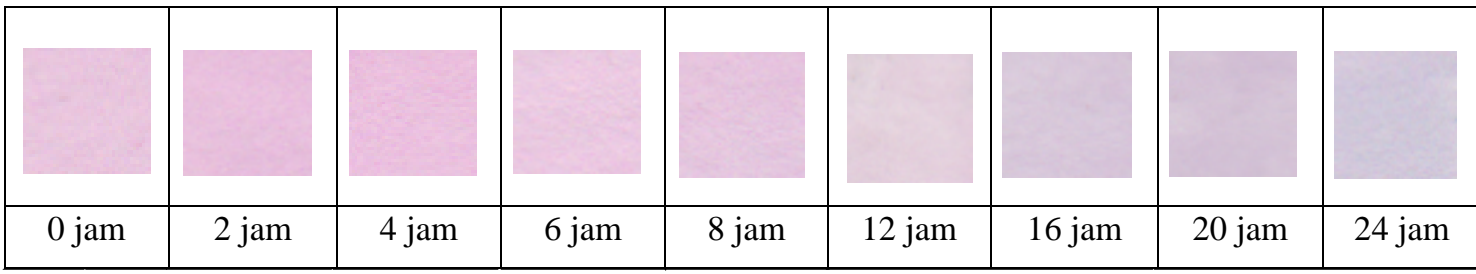

$\begin{array}{ccc}\text { Awal } & \text { Segar } & \text { Masih segar } \\ \text { Mean red } & \text { Mean red } & \text { Mean red } \\ 231.939 \pm & 231.597 \pm 0.275 & 229.485 \pm 0.425 \\ 0.385 & & \\ \text { pH 5.60 } \pm & \text { pH } 5.65 \pm 0.026 & \text { pH 5.82 } \pm 0.025 \\ 0.026 & \text { Warna daging } & \text { Warna daging } \\ & \text { L 52.43 } \pm 0.513 & \text { L 50.72 } \pm 0.705 \\ & \mathrm{a}^{*} 0.52 \pm 0.387 & \mathrm{a}^{*} 1.90 \pm 0.385 \\ & \mathrm{~b}^{*} 3.87 \pm 0.602 & \mathrm{~b}^{*} 3.15 \pm 0.464\end{array}$

Tidak segar
Mean red
$222.029 \pm 0.799$
pH $6.19 \pm 0.027$
Warna daging
L $48.3 \pm 0.645$
$\mathrm{a}^{*} 2.57 \pm 0.372$
b* $2.60 \pm 0.372$

Gambar 3. Perubahan intensitas warna label pintar terhadap tingkat kesegaran daging ayam penyimpanan suhu ruang selama 24 jam

Label pintar berubah warna dari ungu kebiruan (daging ayam tidak segar) pada jam ke 12 .

muda (daging ayam segar), ungu pudar (daging ayam masih segar), dan ungu 


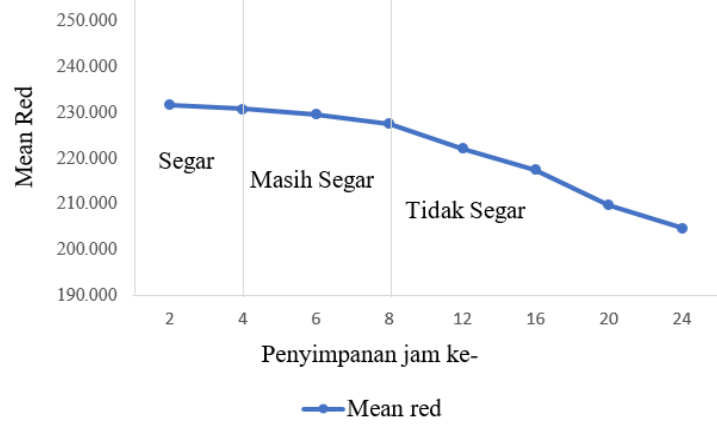

Gambar 4. Grafik perubahan intensitas warna label penyimpanan suhu ruang

Grafik mean red label pintar mengalami penurunan seiring dengan lama penyimpanan daging ayam. Nilai mean red label pintar pada jam ke $2231.597 \pm 0.275$ terus mengalami penurunan hingga ke 24 $204.670 \pm 0.233$. Hasil tersebut menyatakan bahwa label pintar ekstrak antosianin ubi jalar ungu dapat digunakan untuk menentukan tingkat kesegaran daging ayam berdasarkan perubahan visual warna pada label. Nilai mean red pada label pintar semakin rendah maka kesegaran daging ayam semakin menurun, disebabkan terjadi proses pembusukan daging ayam pada suhu ruang. Riyanto et al (2014) menyatakan bahwa proses dekomposisi protein pada daging yang busuk menyebabkan perubahan warna label pintar.

\section{pH Daging Ayam}

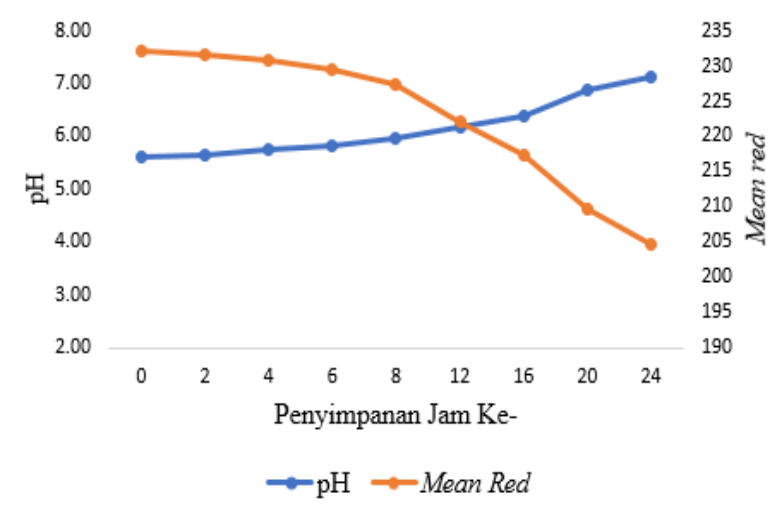

Gambar 5. Hubungan intensitas perubahan mean red dengan $\mathrm{pH}$ daging ayam penyimpanan suhu ruang
Gambar 5 menunjukkan bahwa $\mathrm{pH}$ mengalami peningkatan selama proses penyimpanan daging ayam selama 24 jam pada kondisi suhu ruang. $\mathrm{pH}$ daging ayam jam ke 0 adalah $5.60 \pm 0.026$; jam ke 2 sebesar $5.65 \pm 0.019$; jam ke 4 sebesar 5.74 \pm 0.025 ; jam ke 6 sebesar $5.82 \pm 0.025$; jam ke 8 sebesar $5.96 \pm 0.036$; jam ke 12 sebesar $6.19 \pm 0.027$; jam ke 16 sebesar $6.37 \pm 0.021$; jam 20 sebesar $6.89 \pm 0.035$; jam ke 24 sebesar $7.10 \pm 0.035$. Nitiyacassari (2019) menyebutkan bahwa $\mathrm{pH}$ daging ayam segar \pm 5.68 dan tidak layak konsumsi > 6.05. Arizona et al (2011), pH daging yang semakin tinggi disebabkan oleh mikroba yang mendeminasi asam amino dalam daging sehingga menghasilkan senyawa bersifat basa seperti $\mathrm{NH}_{3}$ dan $\mathrm{H}_{2} \mathrm{~S}$. Label pintar merespon adanya senyawa basa yang dihasilkan dari daging ayam dengan adanya perubahan $\mathrm{pH}$ sehingga terjadi perubahan warna label pintar.

\section{Warna Daging Ayam}

Warna daging ayam diuji pada tiga bagian yang berbeda dan dirata-rata untuk nilai $L, a^{*}$, dan $b^{*}$. Semakin lama penyimpanan nilai $L$ dan $b^{*}$ semakin rendah, sedangkan nilai $a^{*}$ mengalami kenaikan baik pada suhu ruang maupun suhu dingin. Hal ini mengindikasikan bahwa warna daging cenderung berubah menjadi lebih gelap. Perubahan nilai L, a*, dan $b^{*}$ disajikan pada gambar 6 . Penurunan nilai $\mathrm{L}$ dan $\mathrm{b}^{*}$ berkorelasi positif dengan nilai Mean Red label pintar dan berkorelasi negatif dengan nilai a*. Pada 2 jam pertama suhu ruang nilai Mean Red 231.597 \pm 0.275 , nilai L 52.43 \pm 0.513 , nilai a*0.52 \pm 0.387 , dan nilai $b^{*} 3.87 \pm 0.602$. Akhir periode pengamatan nilai Mean Red $222.029 \pm 0.779$, nilai $L$ 48.3 \pm 0.645 , nilai $a^{*} 2.57 \pm 0.372$, dan nilai $b^{*} 2.60 \pm 0.372$.

Dadgar et al (2010) menyatakan bahwa, kecenderungan daging ayam bagian dada menunjukkan nilai $a^{*}$ yang lebih tinggi (lebih merah) ketika nilai $L^{*}$ menurun (menjadi lebih gelap). $\mathrm{pH}$ yang 
rendah akan menghasilkan warna daging yang pucat dan $\mathrm{pH}$ yang lebih tinggi memberikan warna daging yang lebih gelap (Sugiharto dan Mahfudz, 2019).

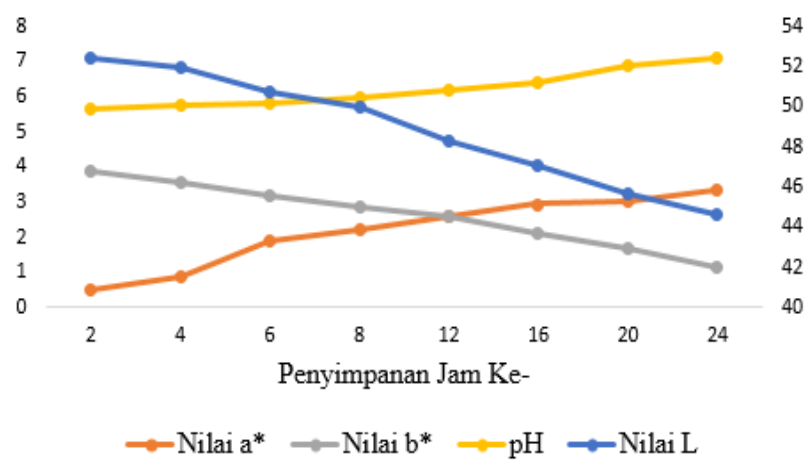

Gambar 6. Perubahan warna daging ayam yang disimpan penyimpanan suhu ruang

\section{Kesegaran Daging Ayam pada Penyimpanan Suhu dingin}

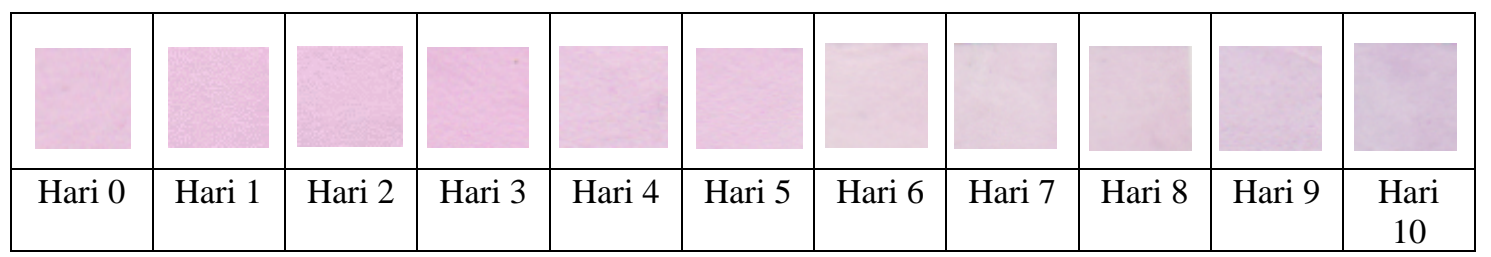

\begin{tabular}{cl} 
Awal & \multicolumn{1}{c}{ Segar } \\
Mean red 231.939 & Mean red \\
\pm 0.385 & $231.681 \pm 0.095$ \\
pH 5.58 \pm 0.015 & pH 5.63 \pm 0.016 \\
Warna daging & Warna daging \\
L 53.38 \pm 0.585 & L 52.48 \pm 0.611 \\
a $^{*} 0.58 \pm 0.306$ & a*0.83 \pm 0.308 \\
b*2.82 \pm 0.634 & b*2.58 \pm 0.440
\end{tabular}

$$
\begin{gathered}
\text { Masih segar } \\
\text { Mean red } \\
229.390 \pm 0.259 \\
\text { pH } 5.83 \pm 0.015 \\
\text { Warna daging } \\
\text { L } 50.87 \pm 0.668 \\
a^{*} 1.03 \pm 0.333 \\
b^{*} 3.48 \pm 0.371
\end{gathered}
$$

Tidak segar Mean red

$221.443 \pm 0.305$

pH $6.13 \pm 0.031$

Warna daging

L $47.32 \pm 0.668$

$\mathrm{a}^{*} 2.10 \pm 0.237$

b* $2.02 \pm 0.313$

Gambar 7. Perubahan intensitas warna label pintar terhadap tingkat kesegaran daging ayam penyimpanan suhu dingin

Kategori perubahan warna label terdiri dari tiga kelompok yaitu ungu muda, ungu pudar dan ungu kebiruan (Gambar 7). Daging ayam tidak layak konsumsi mulai hari ke 7 yang ditunjukkan dengan warna label pintar berubah menjadi bewarna ungu kebiruan.

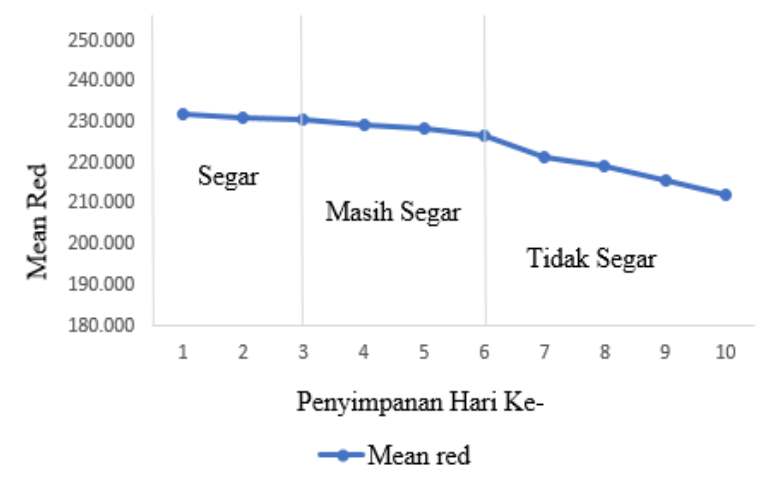

Gambar 8. Perubahan intensitas warna label pintar terhadap daging ayam penyimpanan suhu dingin 
Grafik mean red label pintar mengalami penurunan seiring dengan lama penyimpanan daging ayam pada kondisi suhu dingin. Mean red label pintar hari 1 sebesar $231.681 \pm 0.095$ mengalami penurunan hingga mean red $221.992 \pm$ 0.407 pada hari ke 10. Hasil tersebut menunjukkan bahwa label pintar ekstrak antosianin ubi jalar ungu dapat digunakan sebagai indikator tingkat kesegaran daging ayam penyimpanan suhu dingin. Rahardjo dan Simon (2015) menyatakan bahwa, perubahan warna biosensor terjadi seiring dengan lamanya penyimpanan yang disebabkan karena meningkatnya $\mathrm{pH}$ pada daging ayam akibat adanya komponen basa-basa volatil yang dihasilkan.

\section{pH daging ayam}

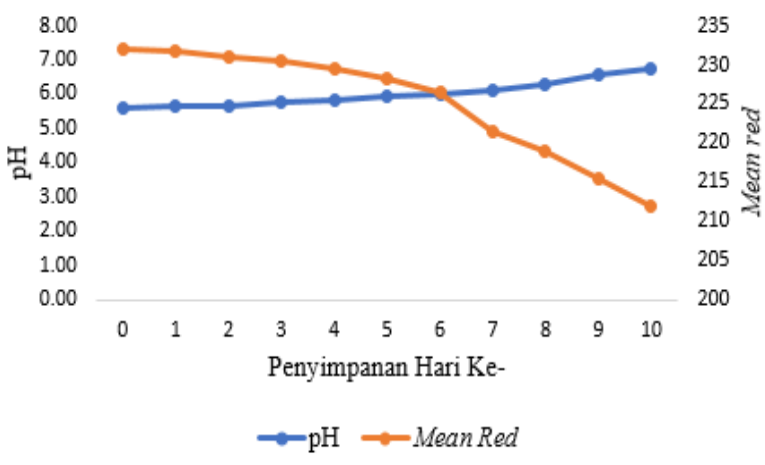

Gambar 9. Hubungan intensitas perubahan mean red label pintar dengan $\mathrm{pH}$ daging ayam yang penyimpanan suhu dingin

Nilai $\mathrm{pH}$ daging ayam pada hari ke 1 sebesar $5.63 \pm 0.015$ mengalami penurunan hingga hari ke enam sebesar $5.98 \pm 0.015$, nilai $\mathrm{pH}$ tersebut dapat dikategorikan bahwa daging ayam masih dalam kondisi segar dan masih layak untuk dikonsumsi. $\mathrm{pH}$ daging ayam pada hari ke tujuh mengalami penurunan sebesar $6.13 \pm 0.031$, nilai $\mathrm{pH}$ tersebut menunjukkan bahwa daging ayam dalam kategori tidak segar atau tidak layak untuk dikonsumsi.

Perubahan $\mathrm{pH}$ dikarenakan adanya hasil pemecahan protein oleh bakteri menjadi senyawa yang bersifat basa antara lain $\mathrm{NH}_{3}, \mathrm{H}_{2} \mathrm{~S}$. Label pintar ekstrak antosianin ubi jalar ungu merespon adanya peningkatan $\mathrm{pH}$ daging ayam akibat terbentuknya senyawa basa yang mudah menguap dengan ditandai perubahan intensitas warna label pintar dan nilai mean red semakin menurun.

\section{Warna Daging Ayam}

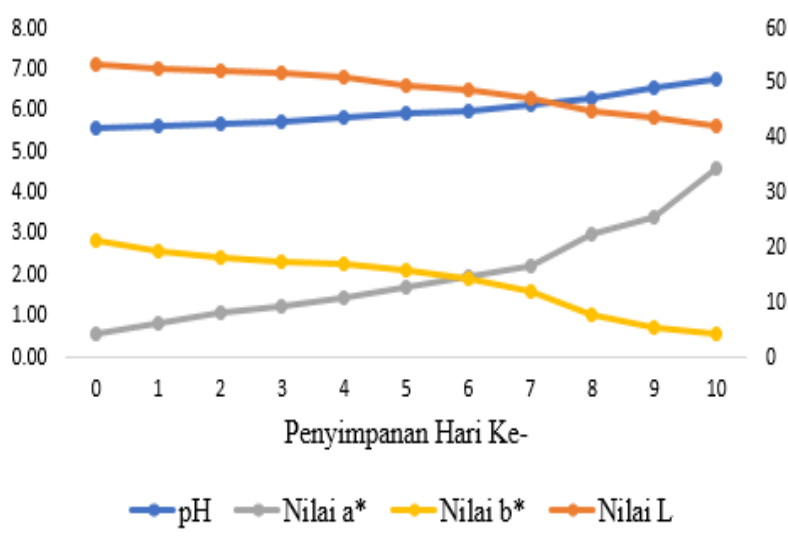

Gambar 10. Perubahan warna daging ayam yang disimpan penyimpanan suhu dingin

Gambar 10 menunjukkan, jika perubahan warna daging ayam dinyatakan dalam L (kecerahan), dimana grafik L terjadi penurunan seiring dengan lamanya masa penyimpanan. Nilai L pada daging ayam penyimpanan hari pertama sebesar $52.48 \pm 0.611$ hingga penyimpanan hari ke sepuluh sebesar 42.02 \pm 0.397 . Gambar 10 menunjukkan jika nilai $a^{*}$ (kemerahan) pada daging ayam yang disimpan selama 10 hari dalam kondisi suhu dingin mengalami peningkatan. Nilai $a^{*}$ pada daging ayam hari pertama sebesar $0.83 \pm 0.611$ hingga hari ke sepuluh penyimpanan sebesar 4.59 \pm 0.417 . Gambar 10 menunjukkan jika nilai $\mathrm{b}^{*}$ (kekuningan) pada daging ayam yang disimpan selama 10 hari pada suhu dingin mengalami penurunan Nilai $b^{*}$ pada daging ayam yang disimpan pada hari pertama sebesar $2.58 \pm 0.440$ hingga penyimpanan hari ke sepuluh sebesar $0.58 \pm 0.264$.

Jaelani et al (2014) menyatakan bahwa daging ayam segar memiliki warna putih kekuningan, warna daging ayam yang disimpan selama 6 hari pada suhu dingin 
bewarna putih memudar, warna daging yang disimpan selama 12 hari bewarna putih kemerahan dan terjadi perubahan warna menjadi kemerahan dan gelap. Soeparno (2015) menyebutkan bahwa perubahan warna daging disebabkan karena adanya perubahan miogloblin sehingga terjadi pembentukkan metmiogloblin (MetMb atau MMb) yang dapat mengakibat diskolorasi permukaan daging sehingga warna daging ayam menjadi berubah. Perubahan warna daging ayam yang dinyatakan dalam nilai $\mathrm{L} \mathrm{a}^{*} \mathrm{~b}^{*}$ dipengaruhi oleh $\mathrm{pH}$, semakin tinggi $\mathrm{pH}$ maka daging ayam bewarna gelap dan nilai mean read mengalami penurunan.

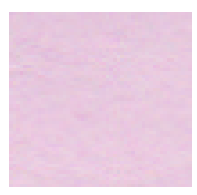

Awal

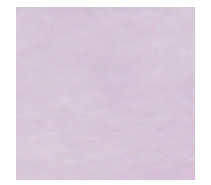

$\mathrm{pH} 7$

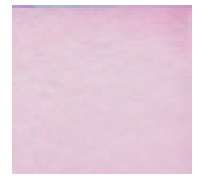

$\mathrm{pH} 4$
Kelayakan Label Pintar Ekstrak Antosianin Ubi Jalar Ungu pada Kemasan Pintar (Smart Packaging) sebagai Indikator Tingkat Kesegaran Daging Ayam di Lapangan.

\section{Uji Stabilitas pH Label Pintrak Ekstrak Antosianin Ubi Jalar Ungu}

Pengujian stabilitas label $\mathrm{pH}$ label pintar ekstrak ubi jalar ungu bertujuan untuk mengetahui perubahan warna label pintar diberbagai kondisi $\mathrm{pH}$ baik pada suasana asam maupun basa.

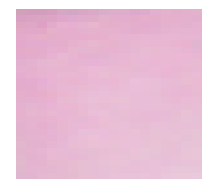

$\mathrm{pH} 1$

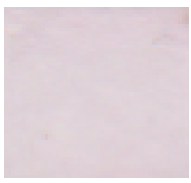

$\mathrm{pH} 7$

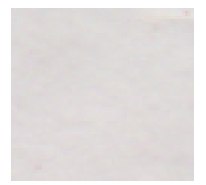

$\mathrm{pH} 11$

Gambar 11. Stabilitas warna label pintar pada suasana asam

Gambar 11 menunjukkan adanya perbedaan intensitas perubahan warna label pintar ekstrak antosianin ubi jalar ungu yang direndam pada larutan $\mathrm{pH} 7, \mathrm{pH} 4, \mathrm{pH}$ 1, pH 7, dan $\mathrm{pH}$ 11. Label pintar esktrak antosianin ubi jalar ungu awal memiliki warna ungu muda, warna label pintar yang direndam pada $\mathrm{pH} 7$ adalah ungu pekat kebiruan, warna label pintar yang di rendam pada $\mathrm{pH} 4$ pada jam ke 8 adalah ungu muda, warna label pintar yang direndam pada $\mathrm{pH}$ 1 pada jam ke 16 adalah ungu kemerahan, kemudian label pintar yang direndam kembali pada $\mathrm{pH} 7$ pada jam ke 24 memiliki warna ungu sedikit kebiruan yang warnanya tidak sama dengan label pintar yang direndam $\mathrm{pH} 7$ pada awal perendaman, dan label pintar yang direndam pada $\mathrm{pH} 11$ memiliki warna kebiruan. Label pintar ekstrak antosianin ubi jalar ungu merespon adanya perbedaan larutan $\mathrm{pH}$ yang digunakan untuk merendam dengan menunjukkan perubahan warna label pintar.

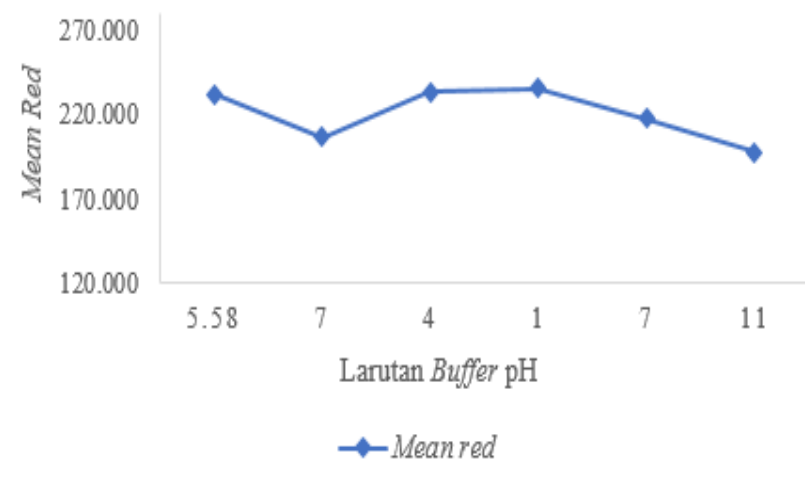

Gambar 12. Nilai mean red terhadap stabilitas warna label pintar suasana asam

Label pintar awal memiliki nilai ratarata mean red sebesar $231.580 \pm 0.246$, pada $\mathrm{pH} 7$ sebesar $206.323 \pm 0.417, \mathrm{pH} 4$ sebesar $233.175 \pm 0.124, \mathrm{pH} 1$ sebesar $235.301 \pm 0.174$, pH 7 sebesar 217.243 \pm 0.197, dan $\mathrm{pH} 11$ sebesar $197.507 \pm 0.372$. Hal tersebut menunjukkan bahwa warna label pintar yang direndam pada larutan asam, dimana $\mathrm{pH}$ semakin rendah maka nilai mean red semakin tinggi. Stabilitas warna label pintar diuji pada suasana basa. 


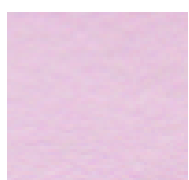

Awal

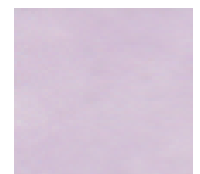

pH 7

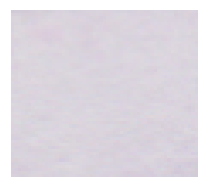

pH 9

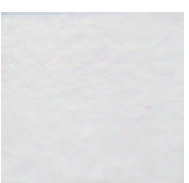

pH 11

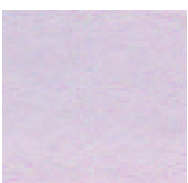

$\mathrm{pH} 7$

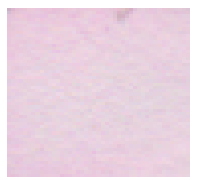

$\mathrm{pH} 4$

Gambar 13. Stabilitas warna label pintar pada suasana basa

Label pintar awal memiliki warna ungu muda, warna label pintar pada $\mathrm{pH} 7$ adalah ungu pekat kebiruan, warna label pintar pada $\mathrm{pH} 9$ pada jam ke 8 adalah ungu kebiruan, warna label pintar pada $\mathrm{pH} 11$ pada jam ke 16 adalah kebiruan, kemudian label pintar yang direndam kembali pada $\mathrm{pH}$ 7 pada jam ke 24 memiliki warna ungu pekat kebiruan dan label pintar yang direndam pada $\mathrm{pH} 4$ memiliki warna ungu muda.

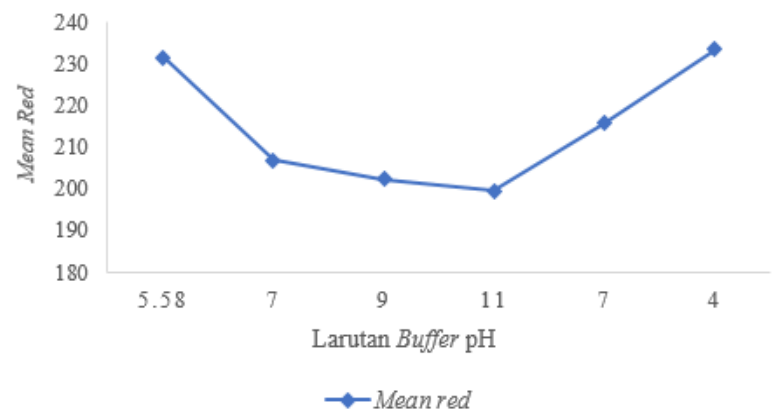

Gambar 14. Nilai mean red terhadap stabilitas warna label pintar suasana basa

Label pintar awal memiliki nilai ratarata mean red sebesar $231.454 \pm 0.090$, pada $\mathrm{pH} 7$ sebesar $206.686 \pm 0.148, \mathrm{pH} 9$ sebesar $202.269 \pm 0.273, \mathrm{pH} 11$ sebesar $199.482 \pm 0.113, \mathrm{pH} 7$ sebesar $215.543 \pm$ 0.154 , dan $\mathrm{pH} 4$ sebesar $233.346 \pm 0.1617$. Nilai mean red label pintar yang direndam pada larutan $\mathrm{pH}$ semakin tinggi memiliki nilai yang semakin rendah. Nilai mean red label pintar berbanding terbalik dengan $\mathrm{pH}$, artinya semakin tinggi larutan $\mathrm{pH}$ yang digunakan untuk merendam label pintar ekstrak ubi jalar ungu maka semakin rendah mean red warna label pintar.

Perubahan warna label pintar pada $\mathrm{pH}$ 1, $\mathrm{pH} 4, \mathrm{pH} 7, \mathrm{pH} 9$, dan $\mathrm{pH} 11$, yaitu dari ungu kemerahan sampai label pintar bewarna kebiruan. Perubahan warna label pintar pada $\mathrm{pH}$ asam lebih stabil dari pada pada pH basa. Imawan et al (2018) menyebutkan bahwa, perubahan warna ekstrak antosianin sensitif terhadap $\mathrm{pH}$ mulai dari $\mathrm{pH}$ asam sampai $\mathrm{pH}$ basa. Warna ekstrak antosianin dikelompokkan pada tiga daerah $\mathrm{pH}$, yaitu merah, ungu dan bewarna dasar biru. Antosianin pada $\mathrm{pH}$ rendah berada dalam bentuk kation flavilium merah, saat $\mathrm{pH}$ dinaikkan akan mempercepat kehilangan proton sehingga membentuk basa quioidal yang cenderung menjadi biru atau ungu, selain itu kenaikkan $\mathrm{pH}$ menyebabkan hidrasi kation flavilium untuk membentuk karbinol (pseudobasa) atau kalkon yang tidak bewarna (Rein, 2005).

2. Ketahanan Label Pintar Ekstrak Antosianin Ubi Jalar Ungu

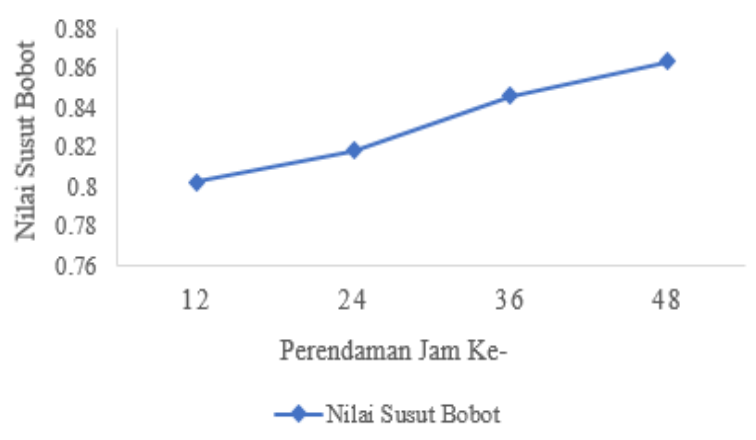

Gambar 15. Perubahan nilai susut bobot label pintar terhadap lamanya waktu perendaman

Nilai susut bobot label pintar ekstrak antosianin ubi jalar ungu berbanding lurus dengan lamanya perendaman yang dapat dilihat pada Gambar 15. Nilai presentase rata-rata susut bobot label pintar yang direndam selama 12 jam sebesar $0.802 \pm$ 0.002 dan mengalami peningkatan hingga pada 48 jam perendeman sebesar $0.863 \pm$ 0.004. Sumiasih et al (2016) bahwa, susut bobot disebabkan karena kehilangan air 
akibat dari proses penguapan. Semakin tinggi nilai presentase susut bobot label pintar ekstrak antosianin ubi jalar ungu disebabkan karena hilangnya kandungan air pada label pintar seiring dengan lamanya waktu perendaman. Perendaman label pintar ekstrak antosianin selama 48 jam label pintar dalam bentuk masih utuh walaupun susut bobot meningkat seiring lamanya waktu perendaman.

\section{KESIMPULAN}

Prototype label pintar yang dikembangkan menggunakan ekstrak antosianin ubi jalar ungu memiliki warna yang stabil pada kondisi asam maupun basa. Label pintar yang dibuat layak diaplikasikan pada smart packaging sebagai indikator kesegaran daging ayam berdasarkan stabilitas warna $\mathrm{pH}$ dan kertahanan kertas label pintar. Tingkat kesegaran daging ayam dikategorikan menjadi tiga yaitu segar (warna label pintar ungu muda), masih segar (warna label pintar ungu pudar) dan tidak segar (warna label pintar ungu kebiruan).

\section{DAFTAR PUSTAKA}

Afandy, M. A., Siti N., Anang W., Diah M. (2017). Ekstraksi Ubi Jalar Ungu (Ipomoea batatas L) Menggunakan Variasi Pelarut serta Pemanfaatannya sebagai Indikator Asam Basa. Jurnal Akademika Kimia 6 (2); Volume 6, No. 2, 79-85.

Ananta, Rosalina., Kusuma, Samuel Budi Wardhana., Harjono. (2017). Film Berbasis Ektrak Antosianin Ubi Jalar Ungu Sebagai Bioindikator Kerusakan Daging Ayam. Indonesian Journal of Chemical Science (1).

Association Official Analitycal Chemistri (AOAC). (2005). Total Monomeric Anthocyanin Pigment Content of Fruit Juice, Beverages, Natural Colorants amd Wines pH Deferential Method.
Arizona, Rizki., Suryanto, Edi dan Erwanto, Yuny. (2011). Pengaruh Konsentrasi Asap Cair Tempurung Kenari dan Lama Penyimpanan terhadap Kualitas Kimia dan Fisik Daging. Jurnal Peternakan Volume 35 No.1, 50-56.

Dadgar, S., E.S. Lee, T.L.V. Leer, N. Burlinguette, H.L. Classen, T. G. Crowe dan P.J. Shand. (2010). Effect of Microclimate Temperature During Transportation of Broiler Chickens on Quality of The Pectoralis Major Muscle. Journal Poultry Sci, 891033-1041.

Farida, R., dan Nisa, F. C. (2015). Ekstraksi Antosianin Limbah Kulit Manggis Metode Microwave Assited Extraction (Lama Ekstraksi dan Rasio Bahan: Pelarut) Jurnal Pangan dan Agroindustri 3 (2), 362-373.

Imawan, Cuk., Fitriana, Rizka., Listyarini., Sholihah, Wafa., dan Pusjiastuti, Wiwik. (2018). Kertas Label Kolorimetrik Dengan Ekstrak Ubi Jalar Ungu Sebagai Indikator Pada Kemasan Pintar Untuk Mendeteksi Kesegaran Susus. Jurnal Kimia dan Kemasan Volume 40 (1), 25-32.

Jaelani, Achmad., Dharmawati, Siti dan Wanda. (2014). Berbagai Lama Penyimpanan Daging Ayam Broiler Segar dalam Kemasan Plastik pada Lemati Es (Suhu $4^{\circ} \mathrm{C}$ ) dan Pengaruhnya terhadap Sifat Fisik dan Organoleptik. Zira'ahVolume 39 No. 3, 119-128.

Rahardjo, K.K.E. \& Simon B. W. (2015). Biosensor $\mathrm{pH}$ Berbasis Antosianin Stroberi dan Klorofil Daun Suji Sebagai Pendeteksi Kebusukan Fillet Daging Ayam. Jurnal Pangan dan Agroindustri 3(2), 333-344.

Rein. (2005). Copigmentation Reactions and Color Stability of Berry 
Anthocyanins. Doctoral Dissertation. University of Helsinki.

Reinking, I. (2007). Imgae J Basic. Departemen of Biology Millersvilley University.

Riyanto, Rudi., Hermana, Irma., dan Wibowo, Singgih. (2014). Karakteristik Plastik Indikator Sebagai Tanda Peringatan Dini Tingkat Kesegaran Ikan Dalam Kemasan Plastik. JPB Perikanan Vol. 9 No. 2, 153- 163.

Soeparno. (2015). Ilmu dan Teknologi Daging. Yogyakarta: Gadjah Mada University Press.

Sugiharto, S R Rini dan Mahfudz, L.D. (2019). Pengaruh Perbedaan Suhu
Pemeliharan terhadap Kualitas Fisik Daging Ayam Broiler Periode Finisher. Jurnal Sains Peternakan Indonesia Volume 14 No. 4.

Sumiasih, Inanpi Hidayati, Octaviani, Linda, Lestari, Dessy Indah dan Yunita, Endah Ratna. (2016). Studi Perubahan Kualitas Pascapanen Buah Belimbing dengan Bebebrapa Pengemasan dan Suhu Simpan. Jurnal Agrin Volume 20 No. 2.

Suradi, K. (2012). Pengaruh Lama Penyimpanan Pada Suhu Ruang Terhadap Perubahan Nilai pH, TVBN, dan Toal Bakteri Daging kerbau. Jurnal Ilmu Ternak. 